\title{
EVALUATING ENJOYMENT OF URBAN REGIONS THROUGH INNOVATIVE CITY INDICATORS WITH AN EMPHASIS ON SOCIAL AND CULTURAL INDICATORS (A CASE STUDY: TABRIZ METROPOLIS)
}

\author{
RASHTBAR H. a NAZMFAR H. ${ }^{\text {b }}$, SAMADZADEH R. ${ }^{a}$ \\ a Islamic Azad University of Ardabil Branch, Ardabil, Iran, e-mails: hadirashtbar65@gmail.com, samadzadeh1347@gmail.com \\ b* Mohaghegh Ardabili University of Ardabil, Ardabil, Iran, e-mail: nazmfar@uma.ac.ir
}

Received: 05.03.2019 / Accepted: 11.04.2019 / Revised: 11.05.2019 / Available online: 31.05.2019

DOI: 10.2478/jaes-2019-0014

KEY WORDS: Innovative City, Tabriz Metropolis, Social and Cultural Indicators, Shannon Entropy, TOPSIS, Spatial Focus.

\begin{abstract}
:
This research aims to define the degree of enjoyment in regions of Tabriz metropolis through innovative city indicators with an emphasis on the social and cultural indicators. In terms of practical purposes, the present study is of applied research type, and in terms of the nature of methodology, it is a comparative research. In this research, Shannon entropy method for weighing criteria is used to determine the weight of each of the indices under study, and a TOPSIS technique is applied in order to rank the regions of Tabriz metropolis to create the innovative city. Emphasizing on the social and cultural indicators, the findings of the research show that region 8 tops the ranking list and region 10 is ranked the last in terms of enjoyment through innovative city indicators. The result of this research indicates that the social and cultural indicators are not distributed equitably to fit well into an innovative city concept, and there is a focus on spatial distribution of indicators. Moreover, the results of this research indicate the incompatibility of the distribution of social and cultural indicators with the distribution of population across the city. Therefore, since innovation is the key to the development and expansion of cities as well as the equitable and rational distribution of services and facilities necessary for development and progress, the fair distribution of social and cultural indicators is essential for the realization of an innovative city.
\end{abstract}

\section{INTRODUCTION}

Today, more than half of the world's population lives in cities, and the population of the world cities is expected to reach 75 $80 \%$ by 2050 . With a hope to have a better life, services and jobs, people move towards cities. The urban population increase by 60 million people every year (Kauppinen, 2016). Cities have been always the centers of innovation, and creativity (Nazmfar et al., 2017), as well as the core motivation to move, combine and direct the creative energy of the mankind (Rabbani Khorasgani et al., 2011), which has been for a long time known as an engine of innovation, creation of community wealth, and an environment for innovation (Bettencour et al., 2007) that should establish sustainable innovation systems to resolve Main issues of sustainability. Although cities are considered as the center for innovation, the innovation level is constant over time and space and/or not evenly distributed (Johnson, 2014). One of the important issues in researches on creative industries as one of the components of innovative city is related to the spatial distribution of these activities. The geographical distribution of creative industries has been analyzed at a variety of scales, and has been investigated in a number of different countries (Gregory \& Rogerson, 2018). Obviously, creative industries are not evenly distributed in space, but are concentrated in specific places. Due to the innovative environments that the city offers, creative clusters focus on the city's central regions (Gregory \& Rogerson, 2018).

Nowadays, the main competition in the process of globalization is between the urban centers and not states and nations. (Ghorbani et al., 2013). In the age of globalization, the rivalry that exists or will exist among cities is to attract expert people. The rivalry now is to attract those who are skilful in technology and information (Ghorbani et al., 2015; Nazmfar et al., 2016). At the present time and in future, cities will have to provide an environment where professionals are encouraged to live, to look for more opportunities (Nazmfar et al., 2017), and to make their expertise available to the community with no concerns (Ghorbani et al., 2015; Nazmfar et al., 2016). But, it should be noted that competitive advantage is not established in every place and every city, and must be provided conditions to them (Mustred, 2010).In fact, experts, artists, researchers and creative people reside in cities with a pleasant environment in cultural, social, institutional and economic aspects (Ghorbani et al., 2015).

Based on the rationale Gregory and Rogerson, creative people opt for identity preferences to work and live in cities with a high level of cultural services. Different urban amenities, such as galleries, museums, exhibition spaces, heritage sites, parks,

\footnotetext{
*Corresponding author: NAZMFAR H., e-mail: nazmfar@uma.ac.ir
} 
libraries, restaurants, cafes and shops, are added to the attractions of creative entrepreneurs (Gregory \& Rogerson, 2018). In 2000, new attention was attracted by Charles Landry as he published 'Creative City". A paradigm that is relevant to the creative class theory of economic development is an expansion of the human capital theory, which predicts economic growth in terms of the educated population residing in the urban area. Florida argues that at times of intensified international competition and rapid technological changes, governments must strive to attract the "creative class" in order to boost their economy and gain competitive advantage over countries not doing the same. The virtuous cycle relies on the ability of cities to attract the creative class by fostering a friendly and innovative environment (Charrieras et al., 2018). University is considered as a place to develop talents and skills in scientific and practical expertise, an aggregation space for the creative class of the community (Gharehbaglou \& Kargar, 2017). In addition, as a part of public open space where social interactions take place, urban open space is the regions in which people can define new structures and their new identities. They are regions for an exchange of thoughts and information, providing a place-focused model for social networks in which individuals and various social groups are involved. Public spaces can be a focus for emergence of creativity and a place to show the creativity of each citizen (Gharehbaglou \& Kargar, 2017). The diversity of population and urban activities is one of the main factors in urban innovation; because innovation is very interactive and is a new structure for different elements of knowledge and skill. Variety in structure, culture, occupation, skills, merits and tastes in the production structure, in terms of company size, the type of organization, and the variety in production and public supply, as well as private goods and services, creates a potential for innovation (Johnson, 2014). More pleasant and diverse locations attract more skilled and creative people that then channel their creativity towards innovation and growth. On the other hand, regions that have more individuals with potential, grow faster and can better attract talent to themselves (Gharehbaglou \& Kargar, 2017). Gifted and creative people are willing to work in a small number of cities or regions, regions that offer favorable conditions, like a vibrant business environment and better social services (Buschemann et al., 2016). In this regard, studies have been conducted by researchers, some of which include:

In an article titled "Understanding Social Innovation in Services Industries", Gallouj et al (2018) focus on the relationship between service innovation and social innovation, and argue that social innovations often result in services. In addition, service innovations become increasingly socialized. This article examines the means through which innovation in services gradually transforms into one of the social innovations. Based on their analysis of this particular subject, it can be completed and revised as follows: understanding and using social goals and social tools in innovation policies; strengthening capabilities in social innovation; empowering users, communities and citizens to generate collaboration and joint innovation; facilitating collaboration between private, public and protected networks; and promoting the scalability of success stories. Gregory \& Rogerson (2018) published an article titled "Suburban Creativity: The Geography of Creative Industries in Johannesburg" with an aim to investigate the location features of creative industries. A general concept of the geography of creative industry in Johannesburg, highly concentrated in the suburbs instead of within city and its marginal regions. However, significant differences have been observed in eight categories of creative industries. Considering the local policies, policies adopted in Johannesburg concerning creative industries are currently under the influence of the mainstream international policies for urban reconstruction based on the focus of creative industries on within city. The results of this study indicate the need to reassess the focus of urban spatial policies with regard to creative industries and recognition of the decentralized outlook of creative industries across Johannesburg. Cermasi (2017) presented Contemporary landscape urbanism principles as innovative methodologies: the design of an armature of public spaces for the revitalization of a shrinking city, and has examined a series of potentials of innovative urbanization strategies in order to revitalize a small town by creating a structure for public spaces, by activating the community activities, and social encounter with a glance at a set of theoretical approaches and studies. The final part of the article presents a set of strategies to transfer open spaces into public spaces in New York City as well as small cities in State of New York. Another research is the one conducted by Shengzu et al (2017) titled "Strategic Thinking on Developing Innovative City to Implement the Strategy of Innovation-Driven Development- Based on the Model of Shenzhen Innovative Development", that is, Innovation and Entrepreneurship Ecosystem. There is another study conducted by Kiuru \& Lnkinen (2017) titled "Predicting Innovative Growth and Demand with Proximate Human Capital: A Case Study of the Helsinki Metropolitan Area" where future development of innovation with human capital in the Helsinki Metropolitan Area. In a research titled "Knowing Communities and the Innovative Capacity of Cities", Capdevila (2017) examined the role of outside actors in the capacity of urban innovation. A study titled "Factor State in Innovative Ecosystems: A Comparison between Brazil and Germany" by Buschmann et al (2016) investigates the two cities of Florianópolis and Münster in two countries of Brazil and Germany, which have been officially recognized as they employ public policies to successfully promote innovation, according to the deep qualitative research and the fundamental theoretical framework. The result is that despite all political, social, and economic differences between Germany and Brazil, the strategies adopted in both cities pursue a similar pattern and have succeeded to promote an ecosystem that causes development in companies, innovativeness in products as well as improvement in services and processes. The results in both regions are related to economic development and creation of a strong cluster linked with highly innovative and competitive organizations, and that innovation expands competitive advantage. Thus, the strengths of innovation should be realized by the governments to develop public policies for promotion of Innovation.

In line with realization of an innovative city, there are cities that have succeeded to create a pleasant economic, institutional, social and cultural environment, for enticing the creative class (Nazmfar et al., 2016, Ghorbani et al., 2015), and through creating a comprehensive innovative ecosystem (concentration, diversity and relationship between elements), an innovative environment (Buschmann et al., 2016) for commercialization and the practicalization of new ideas (Tidd et al., 2012). As the sixth metropolis in Iran, and due to its strategic position, being located at a crossroad towards Europe, Tabriz metropolis is considered one of the commercial hubs of the country. The surveys carried out in East Azerbaijan province show, as the capital of the province, or, in other words, the regional center of 
the north-west of the country, Tabriz involves a very high level of activities and population. This city enjoys cultural, social and economic concentration and diversity, and is among one of the historical cities of Iran. Therefore, the Tabriz metropolis has the potentials to actualize an innovative city; but it still stands far from an innovative city. It is also considered as one of the industrial hubs in the north-west of the country in terms of economic and production infrastructures, especially in the industrial sector, due to the concentration of its huge industrial centers. For this very reason, the city has reached the top level of development on its own, and has created a huge gap too difficult to be bridged with other cities. This indicates an intense population density and focused activities and services in Tabriz, which has led to the migration to Tabriz and an increase in its population, and the Tabriz metropolis has thus been facing social, economic, physical and environmental challenges. Considering that the facilities and services of Tabriz metropolis are not evenly distributed, the development and expansion of cities require fair distribution of facilities and services among urban regions. In addition, these facilities and services are measured as a motivation for innovation, as innovation is the key to the development and growth of cities, and provides a competitive advantage for the cities. Hence, the ways of social and cultural indicators distribution in the regions of Tabriz metropolis are indispensable to the fulfilment of an innovative city. This research aims to measure the enjoyment of Tabriz metropolis through innovative city indicators with a focus on social and cultural indicators.

\subsection{Study Area}

Tabriz metropolis is the capital of East Azerbaijan province, with an area of 25,056 hectares, and latitude ranging from 38 degrees, 1 minute, to 38 degrees, 8 minutes north, and longitude ranging from 46 degrees, 5 minutes to 46 degrees, 22 minutes east. The average estimated elevation of the city is 1,460 meters higher from the global sea level (Naghsh Mohit Consulting Engineers, 2014). According to the census of the Iranian year started 2016, the Tabriz metropolis is considered to be the sixth largest city in the country, with a population of $1,558,693$ (Figure 1).

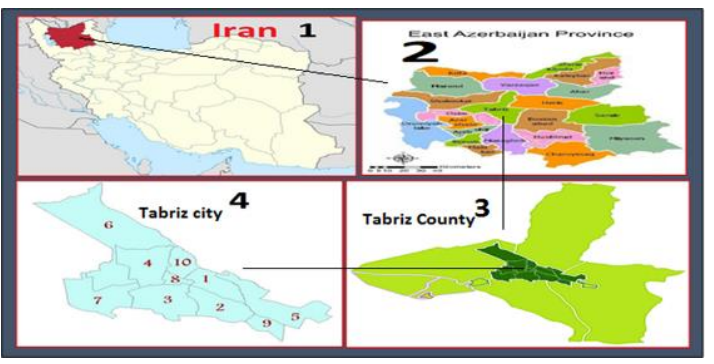

Figure 1. Geographical Location of Study Area (Tabriz Metropolis)

\section{RESEARCH METHODOLOGY}

The methodology adopted for this research is based on three principal stages as follows:

1. Library Studies: At this stage, a variety of books, articles and documents on the research theoretical framework, background and the location of the city as well as analysis of the data have been studied.
2. Field Study: The data has been obtained from the relevant organizations, both in person and through the related websites, as well as using the Google Earth to spot the locations of innovation indicators in a belt of ten districts under study.

3. Data Analysis: In terms of practical purposes, the present study is of applied research type, and in terms of the nature of methodology, it is a comparative research. In order to determine the weight of each of the 40 components of social and cultural indicators in this research, Shannon entropy method for weighing criteria is used, while multi-criteria decision-making (MCDM) technique is applied to rank the districts of regions of Tabriz metropolis based on these indicators to realize the innivative city.

Shannon Entropy Method: This method calculates the weights associated with each index based on the distribution of the index-related values. Entropy will be able to receive the obtained set of weights and adjust them based on the model if the decision makers have an initial assessment of the indicators. Thus, when the entire data of a decision matrix is accepted, Entropy method can be used to determine the weights of the evaluating indicators. (Hajinejad et al., 2016; Pourtaheri, 2015). In other words, in information theory, entropy is a criterion to quantify the degree of uncertainty expressed by a discrete probability distribution function, defined by (Hajinejad et al., 2016):

$$
\mathrm{E}_{\mathrm{j}}=-\mathrm{K} \sum_{\mathrm{i}=1}^{\mathrm{M}}\left[\mathrm{P}_{\mathrm{ij}} * \mathrm{LnP}_{\mathrm{ij}}\right]
$$

Where: $\mathrm{Ej}=$ value of confidence

$\mathrm{Pj}=$ normalized value of the $\mathrm{i}$-th parameter in $\mathrm{j}$ indicator.

The TOPSIS technique: As a multiple-attribute decision-making (MADM) method, TOPSIS is considered a simple and efficient method of prioritization. This model is a very robust compensatory MADM to prioritize options by simulating an ideal solution, with lower sensitivity to the type of technique of weighting, and the resulting responses do not profoundly change. In this method, the selected option should have the shortest distance from the ideal response and the farthest distance from the most inefficient response (Nazmfar et al., 2016; Pourtaheri, 2015)

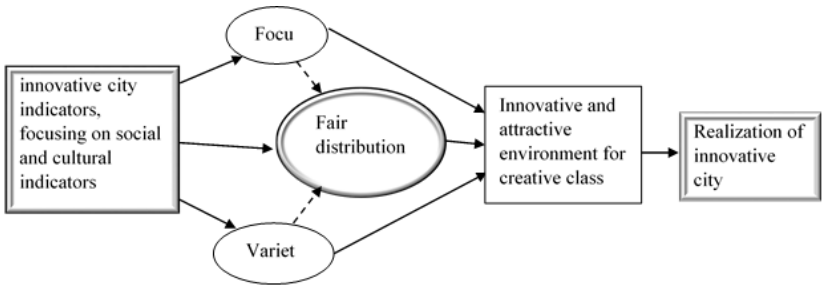

Figure 2. Conceptual Model

The conceptual model of the research suggests the realization of the innovative city by generating an enticing and pleasant environment to attract the creative class through a fair and logical distribution of urban indicators, with an emphasis on social and cultural indicators. This process introduces a 
comprehensive innovative ecosystem in order for the innovative city to be realized and formed (Figure 2).

city with an emphasis on the social and cultural indicators will be compared and ranked (Table 1, 2 and 3).

\subsection{Research Community}

Tabriz as a metropolis has ten regional municipalities. The region 9 has not included in this study because it is uninhabited.

Therefore, in this research, nine regions of Tabriz metropolis as a research population based on the indicators of the innovative

Table 1. Population of Metropolis Tabriz Based on 2016 Census

\begin{tabular}{|l|l|l|l|l|l|l|l|l|l|l|}
\hline & Region 1 & Region 2 & Region 3 & Region 4 & Region 5 & Region 6 & Region 7 & Region 8 & Region 9 & Region 10 \\
\hline Population & 218647 & 196507 & 229474 & 315183 & 126124 & 98910 & 155872 & 29384 & 634 & 187958 \\
\hline
\end{tabular}

Table 2. Research Indicators

\begin{tabular}{|c|c|c|c|c|c|c|c|}
\hline $\begin{array}{l}\text { Population } \\
\text { concentration }\end{array}$ & $\mathrm{X} 1$ & $\begin{array}{l}\text { Higher-education } \\
\text { per capita }\end{array}$ & $\mathrm{X} 11$ & $\begin{array}{l}\text { Newsstand Per capita } \\
\text { (per } 10.000 \text { people) }\end{array}$ & X21 & $\begin{array}{c}\text { Number of book publication } \\
\text { and bookstore (per } 10.000 \\
\text { people) }\end{array}$ & X31 \\
\hline $\begin{array}{l}\text { The proportion of } \\
\text { immigrants to the } \\
\text { total immigrants }\end{array}$ & $\mathrm{X} 2$ & $\begin{array}{c}\text { park space Per } \\
\text { capita (per } 10.000 \\
\text { people) }\end{array}$ & $\mathrm{X} 12$ & $\begin{array}{l}\text { Number of single- } \\
\text { purpose cultural } \\
\text { institutions (per } \\
10.000 \text { ) } \\
\end{array}$ & X22 & $\begin{array}{l}\text { Number of conferences, } \\
\text { festivals and exhibitions }\end{array}$ & X32 \\
\hline $\begin{array}{l}\text { The proportion of } \\
\text { university students } \\
\text { to total population }\end{array}$ & $\mathrm{X} 3$ & $\begin{array}{l}\text { Women's park per } \\
\text { capita (per } 10.000 \\
\text { people) }\end{array}$ & $\mathrm{X} 13$ & $\begin{array}{c}\text { Number of } \\
\text { multipurpose cultural } \\
\text { institutions (per } \\
10.000 \text { people) }\end{array}$ & X23 & $\begin{array}{l}\text { The rate of participation in } \\
\text { exhibitions, conferences, } \\
\text { festivals proportionate to the } \\
\text { total population }\end{array}$ & X33 \\
\hline $\begin{array}{l}\text { Alumni ratio to total } \\
\text { population }\end{array}$ & $\mathrm{X} 4$ & $\begin{array}{c}\text { toy store Per } \\
\text { capita (per } 10.000 \\
\text { people) }\end{array}$ & X14 & $\begin{array}{c}\text { Number of } \\
\text { publications (per } \\
10.000 \text { people) }\end{array}$ & X24 & $\begin{array}{l}\text { The number of private art } \\
\text { schools (per } 10.000 \text { people) }\end{array}$ & X34 \\
\hline $\begin{array}{l}\text { Percentage of } \\
\text { literates }\end{array}$ & X5 & $\begin{array}{l}\text { theatre hall Per } \\
\text { capita (per } 10.000 \\
\text { people) }\end{array}$ & $\mathrm{X} 15$ & $\begin{array}{c}\text { The number of } \\
\text { advertising institutions } \\
\text { (per } 10.000 \text { people) }\end{array}$ & X25 & $\begin{array}{l}\text { The number of book-reading } \\
\text { stations (per } 10.000 \text { people) }\end{array}$ & X35 \\
\hline $\begin{array}{l}\text { educational centers } \\
\text { Per capita }\end{array}$ & X6 & $\begin{array}{c}\text { Showroom } \\
\text { capacity (per } \\
10.000 \text { people) } \\
\end{array}$ & X16 & $\begin{array}{c}\text { Number of urban } \\
\text { elements (per } 10.000 \\
\text { people) }\end{array}$ & X26 & $\begin{array}{c}\text { number of NGOs (per } 10.000 \\
\text { people) }\end{array}$ & X36 \\
\hline $\begin{array}{l}\text { Sports centers per } \\
\text { capita }\end{array}$ & $\mathrm{X} 7$ & $\begin{array}{l}\text { Cultural centers } \\
\text { per capita (per } \\
10.000 \text { people) }\end{array}$ & $\mathrm{X} 17$ & $\begin{array}{l}\text { Number of seats in the } \\
\text { cinema (per } 10.000 \\
\text { people) }\end{array}$ & X27 & $\begin{array}{c}\text { Number of hotel beds (per } \\
10.000 \text { people) }\end{array}$ & X37 \\
\hline $\begin{array}{l}\text { Historical heritage } \\
\text { per capita }\end{array}$ & X8 & $\begin{array}{l}\text { Public library per } \\
\text { capita (per } 10.000 \\
\text { people) }\end{array}$ & $\mathrm{X} 18$ & $\begin{array}{c}\text { Percentage of } \\
\text { households with } \\
\text { computers }\end{array}$ & X28 & $\begin{array}{c}\text { Number of beds of Hotel } \\
\text { Apartments (per } 10.000 \\
\text { people) }\end{array}$ & X38 \\
\hline $\begin{array}{l}\text { Religious centers } \\
\text { per capita }\end{array}$ & X9 & $\begin{array}{l}\text { The proportion of } \\
\text { library members } \\
\text { to the total } \\
\text { population }\end{array}$ & X19 & $\begin{array}{c}\text { Number of health } \\
\text { centers (per } 10.000 \\
\text { people) }\end{array}$ & X29 & $\begin{array}{c}\text { Number of state office } \\
\text { counters (per } 10.000 \text { people) }\end{array}$ & X39 \\
\hline $\begin{array}{l}\text { Recreational and } \\
\text { touristic centers per } \\
\text { capita }\end{array}$ & $\mathrm{X} 10$ & $\begin{array}{l}\text { Percentage of } \\
\text { literate women }\end{array}$ & $\mathrm{X} 20$ & $\begin{array}{l}\text { The ratio of patients } \\
\text { visiting health centers } \\
\text { to the total population }\end{array}$ & X30 & $\begin{array}{l}\text { Number of ticket-selling } \\
\text { offices (per } 10.000 \text { people) }\end{array}$ & X40 \\
\hline
\end{tabular}

Table 3. The Final Ranking of Options with TOPSIS Model

\begin{tabular}{|lllllll|}
\hline REGION & $\mathbf{S}_{1}^{+}$ & $\mathbf{S}_{1}^{-}$ & SUM & TOPSIS value & Ranking \\
\hline Region 1 & 0.201 & 0.023 & 0.224 & 0.103 & 7 & 3 \\
Region 2 & 0.203 & 0.035 & 0.238 & 0.147 & 2 & Region priority \\
Region 3 & 0.200 & 0.044 & 0.244 & 0.180 & 6 & Region 3 \\
Region 4 & 0.231 & 0.028 & 0.259 & 0.108 & Region 2 & Region 7 \\
Region 5 & 0.209 & 0.013 & 0.222 & 0.059 & 5 & Region 6 \\
Region 6 & 0.207 & 0.028 & 0.235 & 0.119 & Region 4 \\
Region 7 & 0.207 & 0.029 & 0.236 & 0.123 & Region 1 \\
Region 8 & 0.052 & 0.205 & 0.257 & 0.798 & 9 & Region 5 \\
Region 10 & 0.210 & 0.012 & 0.222 & 0.054 & Region 10 \\
\hline
\end{tabular}


According to the Census 2016, region 4 with 315183 population is the most populated and region 9 with 634 population is the least populated region of Tabriz (Figure 3).

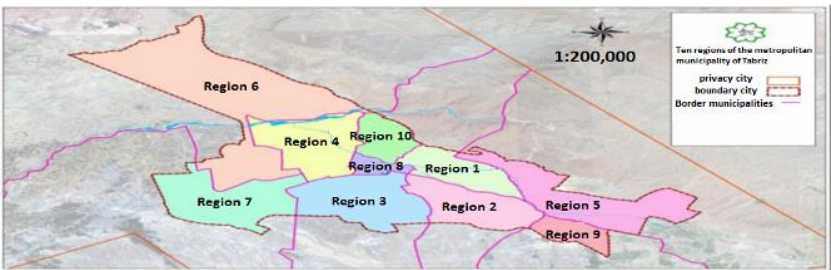

Figure 3. Geographic Location of the Community (Ten Regions of Tabriz Metropolis)

\section{FINDINGS AND DISCUSSION}

In this research, nine regional municipalities of metropolitan Tabriz area will be compared together based on assessing the enjoyment degree of the indicators of the innovative city with an emphasis on the social and cultural indicators. In this regard, Shannon Entropy weighting method is used for weighting the indicators. then, based on TOPSIS technique ,nine urban region will be ranked in terms of having innovative city indicators. According to the results of Shannon Entropy method, the indicator of library members in proportion to the population with 0.05926 has assigned the highest weight and the index of percentage of literate people with 0.00003 has assigned the lowest weight among indicators of social and cultural in line with realization of the innovative city.

\subsection{The Ranking of Nine Urban Regions based on the Indicators of an Innovative City with an Emphasis on Social and Cultural Indicators}

TOPSIS technique has been used to rank and analyze the nine regions of Tabriz metropolis in terms of social and cultural indicators in order to realize the innovative city. Therefore, 40 components of social and cultural indicators are selected for the ranking of regions, as indicated in the table 2 and 3 .

According to the findings of the TOPSIS technique, Region 8 is in the first rank in terms of social and cultural indicators and the Region 10 is in the last rank with the lowest value of social and cultural indicator. Considering the TOPSIS values in terms of social and cultural indicators in the regions as of Tabriz metropolis, Region 8 have full enjoyment, and the rest of the regions are less enjoyable in terms of social and cultural indicators regarding the realization of innovative city.

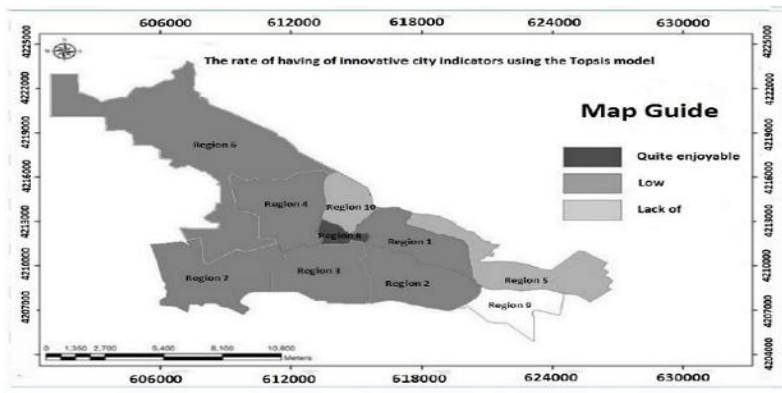

Figure 4. Degree of enjoyment in regions of Tabriz metropolis through innovative city indicators with an emphasis on the social and cultural indicators
According to the TOPSIS values, the ranking of the regions is as $8,3,2,7,6,4,1,5$, and 10 . Therefore, considering the population, region 8 has full enjoyment; regions 3, 2, 7, 6, 4, and 1 have low enjoyment, and regions 5 and 10 face the lack of enjoyment in terms of indicators of the innovative city with an emphasis on social and cultural indicators, as shown in Figure 4. Region 9 is not included in this study because it is vacant, and it is not shown on the map guidance in Figure 4. Findings of the research indicate that there is a large gap between the region 8 and other regions in terms of enjoyment of innovative city indicators.

\section{CONCLUSION}

In order to conduct the research, first, the data related to each of the indicators were collected and using the Shannon entropy weighting method, the weight of each of the studied indicators was determined. Then, to measure the enjoyment of the regions in Tabriz metropolis by the indicators of innovative city with emphasis on the social and cultural indicators, have been used of the TOPSIS technique. The result of this research shows that social and cultural indicators are not equally distributed in line with realization of the innovative city and there is a spatial focus on distribution of the indicators. Likewise, the research findings indicate that the distribution of innovative city indicators with the emphasizing the social and cultural indicators is not consistent with the population distribution. Therefore, considering that innovation is the key of development and promotion of cities and the fair and reasonable distribution of services, facilities are prerequisite for improvement, thus fair distribution of social, and cultural indicators are the necessities for the realization of the innovative city. Therefore, regarding the results of the research, the management of Tabriz metropolis requires attention in the fair distribution of social and cultural indicators in order to realize the innovative city. Therefore, the fair distribution of the innovative city indicators will lead to the development of the city and gaining competitive advantage among cities in the process of globalization. Likewise, the studies conducted in East Azarbaijan province represent that Tabriz, as the capital of the province, has a very high level of activity and population. This city, regarding the economic and manufacturing infrastructures, especially in the industrial sector due to the concentration of industrial centers, is one of the industrial poles in the northwest of the country. Therefore, the city alone has developed to the first level of development and has created a deep gap with other cities. This indicates a strong concentration of population and activities and services in Tabriz that led to the migration to Tabriz and the growth of its population, and made Tabriz metropolis facing with social, economic, physical and environmental challenges. Therefore, there is a need to stimulate innovation through the equal distribution of innovative city indicators to realize an innovative city for economic growth and finding solutions for social, economic, physical and environmental challenges.

\section{References:}

Bettencourt, L. M., Lobo, J., Helbing, D., Kühnert, C., \& West, G. B., 2007. Growth, innovation, scaling, and the pace of life in cities. Proceedings of the national academy of sciences, 104(17), 7301-7306. 
Buschmann, A., Meyer, B., \& Schewe, G., 2016. Factor State in Innovative Ecosystems: A Comparison between Brazil and Germany. International Journal of Innovation, 4(2), 198-207.

Capdevila, I., 2018. Knowing communities and the innovative capacity of cities. City, Culture and Society, 13, 8-12.

Cermasi, O., 2017. Contemporary landscape urbanism principles as innovative methodologies: the design of an armature of public spaces for the revitalisation of a shrinking city. The Journal of Public Space, 2(2), 111-126.

Charrieras, D., Darchen, S., \& Sigler, T., 2018. The shifting spaces of creativity in Hong Kong. Cities, 74, 134-141.

Exenberger, A., Strobl, P., Bischof, G. \& Mokhiber, J., 2013. Globalization and the City, Innsbruck university press, p: 221.

Gallouj, F., Rubalcaba, L., Toivonen, M., \& Windrum, P., 2018. Understanding social innovation in services industries, Industry and Innovation, 25 (6), 551-569.

Gharehbaglou, M., \& Kargar, T., 2017. New Insight into the Creative Urban Clusters (The potentials of joint space between Naqhsh-e Jahan Square and the Art University of Isfahan as an attractive place for the creative class). BAGH-E NAZAR, 13(45), 47-66.

Ghorbani R. et al., 2015. An Overview on New Patterns of Urban Planning. Foruzesh: Tabriz, pp. 1-224, p. 139.

Ghorbani, R., Hossein Abadi, S., \& Toorani, A., 2013. Creative cities: as cultural approach in urban development. Journal of Arid Regions Geographics Studies, 3(11), 1-18.

Gregory, J. J., \& Rogerson, C. M., 2018. Suburban creativity: The geography of creative industriesin Johannesburg. Bulletin of Geography. Socio-economic Series, 39(39), 31-52.

Hajinejad, A., Fattahi, A. \& Paydar, A., 2016. Application of Models and Decision-Making Techniques in Geography by Emphasizing the Rural, Urban and Tourism Programming, Jahad Daneshgahi, Tehran, pp. 1-344, p. 67.

Johnson, B., 2014. Cities, systems of innovation and economic development, Innovation Organization \& Management, 10 (23), pp.146-155.

Kauppinen, H., 2016. Enabling Collaborative Innovation in a Smart City, Creating Scenarios of Open Innovation Platforms Heini, Laurea University of Applied Sciences Leppävaara. pp.7.

Kiuru, J., \& Inkinen, T., 2017. Predicting innovative growth and demand with proximate human capital: A case study of the Helsinki metropolitan area. Cities, 64, 9-17.

Musterd, S., 2002. The Creative Cultural Knowledge City Some Conditions. Paper presented at the University of Kaiserlautern, 28, 10-2002.

Nazmfar, H., Aftab, A., Nazampour, N. \& Majnoony Tootakhane, A., 2016. Evaluation and Prioritization of Urban Areas Based on Parameters Creative City (Case Study: Sanandaj City), pp. 260, 274.
Nazmfar, H., Alavi, S. \& Eseghi, A., 2017. Measuring the Ranking of Urban Settlements of Ardabil Province in terms of Possessing the Creative City, Geography and Environmental Planning, 28 (2), 167-184.

Naghsh Mohit Consulting Engineers, 2014. Development Design and Construction of Tabriz (Comprehensive Plan), City Identification, vol. 4, East Azerbaijan General Roads and Urban Development Organization, p. 33.

Pourtaheri, M., 2015. Application of Multivariate DecisionMaking Methods in Geography, Tehran, pp. 1-224.

Rabbani Khorasgani, A., Rabbani, R., Adibi Sedeh, M. \& Moazeni, A. 2011. Review the Role of Social Diversity in Creating Innovative and Creative Cities (Case Study: Isfahan City). Geography and Development Iranian Journal, 21, 159180.

Shengzu, G., Mei, Y. \& Qinqin, Z., 2016. Strategic Thinking on Developing Innovative City to Implement the Strategy of Innovation-Driven Development-Based on the Model of Shenzhen Innovative Development, Forum on Science and Technology in China,www.cnki.com.cn.

Tidd, J., Bessant, J. \& Pavitt, K., 2012. Managing Innovation, A. Jabbarzadeh \& A. Kahalzadeh, Nashr Daneshgahi Center, Tehran, pp. 1-694. 